\title{
SECULARISM IN TURKEY
}

\author{
Prof. Dr. Bülent DAVER
}

\section{INTRODUCTION}

Secularism (separation of state and religion) is the result and the cause of Atatürk's reforms carried out mainly in the years 1922-1935. This principle, unlike in western countries, had not been realized by the evolutionary currents and ideas of philosophers, disseminated among large parts of the people throughout the centuries, but rather by direct and resolute action and revolutionary enthusiasm of a considerably small elite composed of bureaucrats and young army officers. The Turkish intelligentsia led by Atatürk sought secularism as a modernizing principle as well as a progressive idea covering not only the political and governmental life but a whole social and cultural milieu which was, in its very nature, dominated by superstitions, dogmas and ignorance. Those factors prevented the Turkish people from becoming a modern and prosperous nation. However, very strictly applied in the years of one party rule, the principle of secularism was never meant, in the eyes of its proponents, to be a new dogma or a new religion to replace the old Islam. Instead the republican leaders were very careful not to attack Islam as a faith. Their purpose was rather to "purify" Islam and to open the gate for a reformist Islamic thought and a modern state. Their war-cry was to bring an end to the supremacy of Ulema (Muslim religious officials) and their allies. Thus the secularist movement in Turkey appeared mainly as an anti-clerical drive, a protest at the tyranny of religious fanaticism. Indeed, in Islamic thought and system there was no place for a special clergy or superstitions.

Beginning from 1945 with the new era of the multi-party system under President Inönü there was some easing and relaxation in governmental policies concerning religion and secularism. After 1950, with the crushing victory of the Democrat Party in the general elections, easing the curbs on religious liberties had reached such a point a some Western observess have often used the expression "The Islamic revival in Turkey". However, this policy of giving too much credit to conservative circles was opposed mainly by the Republican People's Party (a party which was 
founded by Atatürk in 1923). The reformist and revolutionary circles and elites saw the religious policy of the Democrat Party as treason to the Kemalist principles. One of the main causes in the appearance of the military's intervention of 27 May 1960 was the "desire to bring an end to the exploitation of religion for political and private purposes".

For a foreign scholar there can be some inconsistency, if not contradiction, in the application of the principle of secularism in Turkey. For instance, the state (government) controls religious affairs and organizes it as a deparment of State. Each year a great deal of money is poured out from the State budget for religious affairs. ${ }^{1}$ Indeed, today almost sixty thousand religious officials receive their salary from the state budget (During the early years of the Republic this figure was around five hundred). In the realm of religious liberties there were some limitations which can seem "excessive" to a liberal- minded foreign observer. These limitations and exceptional measures regarding religious matters can only be explained in terms of Turkey's special historical and social structure and conditions. The students of Turkish affairs are very well aware of these special factors. Our purpose in this paper is to make a short outline of the secularist movement in Turkey, and to try to give an answer to some questions raised by the delicate problems of the relationship between state and religion.

In our opinion the most difficult task for Turkey's presenty-day leaders, in the era of the multi-party system, is to make a convenient arrangement to bring about a broad consensus concerning religion's proper role in a modern democratic state. This task necessitates a consensus among contending parties and leaders. Some of them are acting in the name of Atatürk's principles and others are speaking on behalf of democracy. However, we can say that the secularisation of the masses is still the great unfinished mission of Turkish elites. A convenient balance between the progressive ideas of Atatürk and the needs of a pluralistic society requires a subtle analysis of the situation as well as dedication and courage on the part of leaders.

\section{HISTORICAL BACKGROUND}

\section{Ottoman Period}

The Ottoman Empire was a theocratic state like the other Turkish states which appeared on the scene of history, beginning from the $10^{\text {th }}$

For a detailed analysis of the subject: Dr. Bülent Dâver, Türkiye Cumhuriyetinde Lâiklik (Secularism in Turkish Republic), Ankara, 1955. 
until $15^{\text {th }}$ centuries. The Sharia (Holy Koran) was a fundamental law for believers as well as the rulers. But few Muslim rulers in history have made it, in practice, the main business of the state. The Koran is intended to enforce God's eternal laws.

Administrative, criminal, civil and commercial law have, almost from the beginning of Islamic society, been separated from the domain of the Sharia, though this separation was not formally and explicity codified until $19^{\text {th }}$ century. ${ }^{2}$

Islam had also reconciled itself to the separation between religion and the conduct of the state in foreign affairs once it acquiesced in the peaceful coexistence of orthodox Islamic states with the Christian and heterodox Islamic nations. As Majid Khadduri pointed out: "The principle of peaceful relationship among nations of different religions is perhaps the most revolutionary Islamic legal theory and this was for the first time embodied in a treaty signed in 1533 between Francis I of France and Suleiman the Magnificent, Sultan of the Ottoman Empire."

Despite these facts the hold of Islam on the state as well as on believers was very strong, for Islam was not only a faith, a credo, but also a legal system aiming at organizing the whole life, including political, social, civil and cultural spheres. The first reaction to Islam's claim to administer all these matters, concerning the temporal world, came during the Tanzimat period which was promulgated in 1839 by a Ferman (Royal Decree) of Sultan. The Tanzimat's administrators, who had been influenced by Western institutions, saw the impossibility of conducting state affairs in a rapidly changing world according to old religious principles. Under the heavy pressure of events they felt obliged to introduce western laws and institutions in Turkey, which were based on modern principles existing in modern nations.

Another breach in the orthodox Islamic system was the introduction of public schools which were essentially secular in their nature. Furthermore, along with the religious courts which were dealing with private cases of citizens, special secular courts in the western style were created. The judges appointed to these new courts were different in their approach as well as in their education from their colleagues in the Sharia courts.

2 Manfred, Halpern; The Politics of Social Change in the Middle East and Africa, Princeton University Press, 1963, p. 130.

3 Majid Khadduri; "The Islamic System: Its Competition and Coexisience with Western Systems", Proccedings of the American Society of International Law, 1054, p. 51. 
Despite these steps of secularization and modernization the Ottoman Empire was still mainly theocratic in character and outlook, because the Sultan was officially the head of all Muslims. The first Constitution of the Ottoman Empire, promulgated in 1876, explicitly stated that the main duty of the Assembly was to carry out the principles of the Sharia. Another article of this Constitution stipulated that the religion of the state was Islam.

\section{Atatürk's Reforms:}

For a radical change in these matters one needed to wait until Atatürk's reforms. After the liberation of the country from the enemy, a series of radical reforms were initiated in order to secularize the state and social life. The first one of these steps was the abolition of the Sultanate in 1922 which was followed by the proclamation of the Republic in 1923.

In 1924 the Caliphate and the Ministry of Religious Affairs "were abolished. In 1925 religious orders (tarikats) were prohibited. A Civil Code in the western style was introduced in 1926. In 1928 the Constitution was amended and the article stating that "the state's religion is Islam" was deleted. Finally, the principle of secularism was formally introduced into the Turkish Constitution by the amendment carried out in 1937. Along with these legal changes came many other reforms secularizing social and cultural life. Religious teachings in public schools were suspended. The public demeanor of women was changed (especially in big cities like Istanbul, Ankara and Izmir). The language of prayers in mosques was changed to Turkish instead of Arabic etc...

After the death of Atatürk in 1938 and with the new era of the multiparty system under President Inönü in 1945, things have somewhat changed. One of the main controversial issues between the Republican People's Party which started secularism and championed it, and the newly created Democrat Party, was the role of religion in Turkish life. Indeed the Republican People's Party itself had made certain concessions after 1945 regarding this matter, under the heavy pressure of the opposition party. For instance, the Republican People's Party had agreed to allow religious instruction in public schools upon the written request of parents. The party also permitted the openning of some religious places such as türbes (mausoleums) to the public. President Inönü's Republican Party also authorized the creation of a Faculty of Theology in Ankara and the training of imams (religious officials). Such measures and steps were defended as a safeguard against fanaticism and obscurantism. 


\section{The Democrats in Power}

In 1950, with a landslide, sweeping electoral victory, the Democrat Party came to power. The Democrats who had been elected on a platform with a concervative tendency had based much of their appeal in representing the wishes of the people, in implied contrast to the imposed reforms during the early years of the Republic by the Republican People's Party. For a large part of the Democratic vote came from conservative, rural areas. ${ }^{4}$ Thus some relaxation in the pressures for the total secularization of Turkish life was allowed during the rule of the Democrat Party. The Democrats extended the number of institutions for the training of imams and allowed them to take on a conservative line. In the field of religious instruction in public (state) schools, the Democrats altered this arrangement to allow all muslim children to receive religious instruction automatically unless their parents requested in writing that their children should not receive such education. Thus religious education was made virtually compulsory in public schools, taking into consideration the fact no parents in Turkey would dare to state explicity that religious instruction was undesirable.

Furthermore, religious education, which was given only in primary schools outside the official curriculum and class hours, was extended to secondary schools after 1950. Taking another step along their way, the Democrats abolished the law prohibiting the use of the Arabic form of the call to prayer (ezan). The entire country immediately dropped the Turkish translation which the early law had substituted. ${ }^{5}$

Other areas of changes in the domain of religious affairs were more unofficial. Ramadan (the Muslim holy month) began to be celebrated more publicly. Religious publications reappeared. The remnants of various mystical orders (tarikats) began tentatively to show their heads. However, one must say that the troublesome sects like the Ticanis and Nurcu were severely dealt with and punished during the 1950's. Under Democrat Party rule, religious associations which had been prohibited in any form under the law of associations promulgated in 1938, began to be founded and their number constantly increased during the years ahead. These religious associations bore the names of "Association for the Construction of Mosques," "Association for the Needy Pupils of Koran Courses" etc. During this period a large amount of governmental funds was used for building

4 Walter F. Weiker; The Turkish Revolution: 1900-1961, The Brookings Institute, Washington D.C. 1965, pp. 8-8.

3 See in this matter an article written by Paul Stirling; "Religious Change in Republican Turkey", Middle East Journal, Autumn 1958, p. 400. 
new mosques in cities, towns and villages. One estimates that some five thousand mosques were built between 1950 and 1960. This was approximately the same figure given by the National Ministry of Education for the construction of new public schools in the same period. One foreign observer dealing with this issue wrote: "This silent struggle for scarce reso urces seems highly symbolic of the greater struggle between the forces of secularism and Islam in Turkey".6

The great struggle between the principles of secularism and Islam has marked a turning point with $27^{\text {th }}$ May 1960 Intervention of the Army led by a group of young officers. The discontent of the Turkish Army with the Democrats should be explained in terms of governmental policies with which the Turkish military authorities disagreed. Among these policies one can state the ambivalence of Democrats towards modernity and secularism as well as ultra-conservative, social, and economic policies in social life. $^{?}$

\section{4. $27^{\text {th }}$ May 1960 Army Intervention}

Indeed General Cemal Gürsel then the Commander of the Land Forces sent a letter on May $3^{\text {rd }} 1960$ to the Government through the Ministry of Defence and listed in this letter a number of steps which he thought the Government must take if the political situation was to be righted. These steps, according to him, included among others, ending the exploitation of religion for political purposes. After the coup of $27^{\text {th }}$ May on many occasions the members of the military rule shared this view.

In July 1961 during the "Yes campaign" for the new Constitution (referandum) the National Unity Committee (NUC) which seized power and put on trial all members of the ex-government, published a pamphlet entitled "Our Constitution Viewed From the Angle of Religion". In this paper it was stated: "To refrain from relying, even partly, on religious grounds for determining the social, economic, political and legal foundation of the State, is advisable for those who wish to exploit it for political or personal purposes."

In the eyes of the members of the NUC the chief task for Turkey was to return to the rapid and drastic reformist policies of Atatürk's era, because the principle of secularism was the hallmark of the period when Atatürk guided the nation.

\footnotetext{
" David Hotham; "Turks Turn Again to Religion", The Times, February 23, 1960.

7 Frederic Frey; The Turkish Political Elite, Cambridge M.I.T. Press, 1965, p. 380.

Cumhuriyet, July 2, 1961.
} 


\section{1961 Constitution}

Thus article 2 of the 1961 Constitution solemnly proclaimed that "The Turkish Republic is a national, democratic, secular and social state". Article 153 of this Constitution stipulated also that: "No provision of this Constitution shall be construed or interpreted as rendering anti-constitutional the Reform Laws which aimed at raising Turkish society to the level of contemporary civilization and of safeguarding the secular charecter, which were effective from the date this Constitution was adopted by popular vote (referandum)".

Finally, the 1961 Constitution strictly forbade the exploitation or abuse of religion under the threat of penalties. Article 19 stated that "No person shall be allowed to exploit and abuse religion or religious feelings or sacred things in any manner whatsoever for the purposes of political or personal benefit or for gaining power, or for even partially basing the fundamental social, economic, political and legal order of the state on religious grounds. Those who violate this prohibition, or those who induce others to do so, shall be punishable under the appropriate laws. In the case of associations and political parties the former shall be permanently closed down by order of authorized courts and the latter by order of the Constitutional Court". 9

However, the Turks argued during many years afterwards about whether the Democrat Party period was a time of betrayel of Atatürk principles, including secularism, which forbade the exploitation of religion, or was the restoration of freedom of religion, in other words, the beginning of a new period of "Islamic revival," "The pertinent fact is that the Democrat Party and the Republican People's Party made the interpretation of secularism an evergoing issue. It was mixed with other issues and served to add fuel to a fire which will continue to smoulder."

According to Dr. Frey, Menderes and his lieutenants actually neither wanted nor could afford a religious reaction which would endanger the very foundations of the secular republic. The Democrat Party, though in favour of a mild religious revival, was basically quite modern in its top personnel and quite committed, in its own way, to a continuation of modernization, even while trying to make political capital out of the religious issue. $^{11}$

A Article 163 of the Turkish Penal Code sanctions in detail the violation of this principle.

10 Weiker; op. cit., p. 9.

11 Frey; op. cit., p. 180. 
Solne people can argue, of course, that heightened interest in religion is perfectly compatible with secularism and modernization. Robinson for example, asserts that by 1960 , despite the existence of a religious conservative element of a politically significant size, it no longer endangered the secular republican state. Islam itself had been undergoing a subtle transformation even at the village level. Economic and social incentives, material well-being, innovations, the machine, commerce and social change no longer appeared as challenges to religion. An accommodations between folk-Islam and modern life was in fact taking place. ${ }^{12}$

But in the eyes of Dr. Weiker the commitment of the Democrat Party to secularism and modernization was substantially quite different from the Kemalist model. According to him, secularism was one of the most central pillars of Atatürk revolution. Secularism was interpreted by Atatürk to mean exclusion of predominant religious influence from public life, and in some cases, it meant discouraging private religious observance as well. After Atatürk's death and especially since rise of opposition parties in 1945 the role of religion in Turkish life has become one of the most important public issues. ${ }^{13}$

Another writer, Dr. Karpat, shared this view. According to him, during the Democrat Party's rule, the easing of previous restraints has helped to undermine the secularist spirit to the benefit of Islam, not the enlightened progressive Islam, but the same old obscurantist, fatalistic type which has dominated the Turkish masses since time immemorial. ${ }^{14}$

Kemalist secularism, in Karpat's opinion, had a different and much more comprehensive meaning in Turkey than in the Western countries. Atatürk's secularism did not limit itself merely to the separation of religion from political affairs. It also aimed at liberating society from the hold of Islam, and bringing about a new type of free individual. It was a nationalist, positivist, scientific-minded, anti-traditionalist, anticlerical secularism. Therefore the critics of Turkish secularism may be theoretically right in that the conception of religion bound to the state also violated the principle of secularism. ${ }^{15}$

However, given the fatalistic and obscurantist nature of religious beliefs among the Turkish masses at that time, I can agree with Özbudun that a mere separation between the state and religion certainly would not to be enough to create a modern society based on national and scientific

\footnotetext{
12 Robinson; The First Turkish Republic, p. 205. See also Lerner and Robinson;

"Swords and Plougshares",. World Politics, vol. XII, October 1966, pp. 19-22.

13 Weiker; The Turkish Revolution 1960-1961, p. 4.

14 Karpat; Turkey's Politics, p. 288.

15 Karpat; op. cit., pp. 271-277.
} 
thinking. Alternatives open to the Kemalist cadres in the 1920's were either to reform Islam radically enough to become a progressive force -Atatürk unsuccessfully tried it in some cases- or to restrict religious liberties to a greater extent than in secular western states. In view of the enormous difficulties involved in the first alternative, it was only natural that the latter course was chosen. ${ }^{16}$

But we must carefully indicate that Atatürk, the most far reaching of the secularists, did not openly challenge the Islamic faith, nor did any of the political leaders who came after him. Their struggle was not with the Islamic creed, but rather with the superstitions and fanaticism which were borrowed from other faiths, and which finally damaged the religion. As W.C. Smith wrote "Every honest Turk felt in his deep conscience that those restrictions on clerical and fanatical forces were necessary". ${ }^{17}$

After this quick review dealing with the origin and evolution of the principle of secularism in Turkey we can conclude that, despite Atatürk's reforms, a gap still remains between the existing social, cultural norms and revolutionary legal norms. In Turkey, officially the most secular of Islamic countries-, perhaps the unique country- religion has not ceased to be a political issue and the likelihood is that in the future it will still provoke much more conflict. Manfred Halpern wrote in this issue: "honest (democratic) balloting makes the Turkish peasant the kingpin of the electorate, yet he has been intellectually and socially more isolated from the Atatürk revolution, and has changed relatively less than any other portion of the population. Appeals to religion may yet become a major substitute for eliciting or retaining rural support, especially if the almost steady increase of the economic benefits to the peasant should cease, either because Turkish planners find good cause to reallocate the distribution of resources, or else because the economy falters. The growth of religious brotherhoods (dervish orders) with hallowed traditional names but highly modern purposes during the past few years, has been increasingly reported in Turkish newspapers and exposed in court trials. A marriage of convenience between them and certain political parties which attack the reforms of Atatürk is by no means excluded". ${ }^{18}$

\section{12 September 1980 Army Intervention}

On 12 September 1980 another army intervention happened. The main reason given for this new intervention was "to establish a solid and

16 Ergun Ozbudun; The Role of Military in Recent Turkish Politics, p. 17.

17 W.C. Smith; "Modern Türkiye Dinî Bir Reforma mı Gidiyor?", Ankara Ilahiyat

Fakültesi Dergisi, 1953, Sayı: 1, sh. 13.

18 Manfred Halpern, op. cit., p. 152. 
healthy democracy and to eliminate the destructive forces which were trying to divide Turkey and were endangering the very essence of the principles of Atatürk's republic". One of these principles was secularism.

Article 24 of the new Constitution which is in a way similar to article 19 of the old Constitution of 1961, deals with freedom of religion and conscience as well as religious education and principle of secularism. According to this article "Everyone has the right to freedom of conscience, religious belief and conviction".

"Acts of worship, religious services and ceremonies shall be conducted freely, provided that they do not violate the provisions of Article 14. ${ }^{19}$

No one shall be compelled to worship, or to participate in religious ceremonies and rites, to reveal religious beliefs and convictions."

The new Constitution made religious education somehow compulsory in schools, thus deviated from the article 19 of the 1961 Constitution, according to which religious instruction was optional. Article 24 of the new Constitution said: "Education and instruction in religion and ethics (morals) shall be conducted under State supervision and control. Instruction in religious culture and moral education shall be compulsory in the curricula of primary and secondary schools. Other religious education and instruction shall be subject to the individual's own desire, and the in case of minors, at the request of their legal representatives."

Dealing with the sanetions of secularism the new Constitution adopted almost the same line of the 1961 Constitution and stipulated that "No one shall be allowed to exploit or abuse religion or religious feelings, or things held sacred by religion, in any matter whatsoever, for the purpose of personal or political influence, or for even partially basing the fundamental social, economic, political and legal order of the State. on religious tenets."

\section{CONCLUSION}

At the end of my paper I can make the following conclusions and remarks:

1. Secularism in Turkey appeared, in the beginning, as a movement which aimed at curbing the supremacy of the Islamic "clergy" which was

10 Article 14 of the Constitution prohibits, inter alia, "creating discrimination on the basis of language, race, religion or sect, or establishing by any other means

- a system of government based in these concepts and ideas". The same article adds: "The sanctions to be applied against those who violate these prohibitions," and those who incite and provoke to the same end and shall be determined by law". 
very strong in political, cultural and social life. The State still controls religious affairs and even organizes it as a department embodied in the general administration. A great number of imams ("Islamic clergy") are civil servants and receive their salary from the government budget. Certainly this is incompatible with the principle of secularism as undersstood and applied in Western countries. Turkish reformers knew well that the Turkish secular state was a kind of "Caesarism". But to adopt a complete secularism, at this stage, meant according to them, to endanger the reforms and to restore the old theocratic state with all its fanaticism and superstitions. Since the religious elements were so strong in the social structure of Turkey it was almost impossible for the state to be able to apply a broad secularism and to secure a complete religious freedom to all.

2. Actually Turkish law-makers do not depend anymore on the ruling of the Sharia in making the appropriate laws for a society which is undergoing a deep social and economic change and which desires to catch up with the speed of modern nations.

3. During the republican era, a national educational system was created, drawing its inspiration not from the religious dogmas of the past, but from the scientific values of modern times. It is true that religious education was suspended, once in public schools, for there were not enough competent and enlightened teachers of religion. Most of the "hodjas" were almost totally ignorant people unaware of the basic knowledge and necessities of modern society. From 1945 onwards with the beginning of the multi-party system period, Turkish leaders tolerated religious teaching in public schools under government auspices and control.

This also may seem irreconciliable, in the eyes of some westerners, with the principle of secularism which forbids religious teaching in public (state) schools. In my opinion, this too, is an exceptional public order measure, dictated solely by the necessities of the time. In the future, when the majority of people attain a degree of maturity enabling them to understand the real meaning of religion, and when the dogmas as well as the superstitions wither away, then the time will come to adopt a complete secularism. Religious affairs will then be the business of private associations and communities as in westeren countries.

4. In my personal opinion, in curbing in some instances the freedom of religion on behalf of the secular state, the Turkish reformers never intended to create a new religion or to suppress Islam, thus banning all moral and religious values in society. The Turkish reformers rather aimed at setting up a new "milieu" for the free development of religious li- 
berties. Some limitations on religion were either inspired by nationalistic feelings (such as the prayers in Turkish in the mosque) or by the strong desire to oppose obscurantism and idleness as in the case of the abolition of the religious orders (tarikats).

5. In the new era, which began with the new Constitution of 1982, one can assume that the easing of some more limitations on religious matters may still be expected in the future. Actually, this had already happened after 1980, especially since with the coming into power of the Motherland Party. These developments certainly aroused much criticisin from the leftist parties and progressive circles. However, after the experience of the 1960 and 1980 interventions, we hope that this time the parties in power from now on will be very cautious in handling religious issues and certainly will not give concessions to fanatical and obscurantist circles.

The secularisation of political leadership and social institutions at this moment seems not very well-established in Turkey. In the domain of social life, religious marriage and polygamy still reign in many regions - especially in some rural areas- despite the reform law which punish such acts. There are some politicians - even in the reformist and socialist parties - who capitalize on religious issues during electoral campaigns.

But viewed from the general perspective of the situation, it can be argued that Turkey today had passed the most critical point and is on the high road of modernization.

The rapid economic and social change will certainly have an enormous impact on the minds and behavior of the leaders, as well as the whole people.

However, taking into the consideration the upheaval of the recent Islamic Revolution in Iran and the fundamentalism of the new Islamic drive in some Islam countries, Turkish political leaders as well as the intellectuals and elites musi courageously defend the dynamic and healthy principles of the Kemalist movement which aims at to establish a modern and prosperous nation. 